\title{
Quantifying the human impact on water resources: a critical review of the water footprint concept
}

\author{
J. Chenoweth ${ }^{1}$, M. Hadjikakou ${ }^{1,2}$, and C. Zoumides ${ }^{3,4}$ \\ ${ }^{1}$ Centre for Environmental Strategy, University of Surrey, Guildford, Surrey, GU2 7XH, UK \\ ${ }^{2}$ Water Research Centre, School of Civil \& Environmental Engineering, University of New South Wales, Sydney, \\ NSW, 2052, Australia \\ ${ }^{3}$ Department of Environmental Science and Technology, Cyprus University of Technology, Lemesos, Cyprus \\ ${ }^{4}$ Energy, Environment and Water Research Center, The Cyprus Institute, P.O. Box 27456, Nicosia 1645, Cyprus \\ Correspondence to: J. Chenoweth (j.chenoweth@surrey.ac.uk)
}

Received: 28 June 2013 - Published in Hydrol. Earth Syst. Sci. Discuss.: 17 July 2013

Revised: 25 April 2014 - Accepted: 26 April 2014 - Published: 24 June 2014

\begin{abstract}
The water footprint is a consumption-based indicator of water use, referring to the total volume of freshwater used directly and indirectly by a nation or a company, or in the provision of a product or service. Despite widespread enthusiasm for the development and use of water footprints, some concerns have been raised about the concept and its usefulness. A variety of methodologies have been developed for water footprinting which differ with respect to how they deal with different forms of water use. The result is water footprint estimates which vary dramatically, often creating confusion. Despite these methodological qualms, the concept has had notable success in raising awareness about water use in agricultural and industrial supply chains, by providing a previously unavailable and (seemingly) simple numerical indicator of water use. Nevertheless, and even though a range of uses have already been suggested for water footprinting, its policy value remains unclear. Unlike the carbon footprint which provides a universal measure of human impact on the atmosphere's limited absorptive capacity, the water footprint in its conventional form solely quantifies a single production input without any accounting of the impacts of use, which vary spatially and temporally. Following an extensive review of the literature related to water footprints, this paper critically examines the present uses of the concept, focusing on its current strengths, shortcomings and promising research avenues to advance it.
\end{abstract}

\section{Introduction}

Modern human societies use vast amounts of water, with increasing competition for scarce water resources impacting heavily on present and future human welfare and the state of our natural environment. As part of the search for an effective sustainability indicator for water resource use, the water footprint has grown rapidly in prominence since being proposed a decade ago. Numerous papers have been published, conferences held, and an international Water Footprint Network (WFN) established. Furthermore, the water footprint concept has received increasing press coverage, and a growing number of countries ${ }^{1}$, companies (Coca-Cola and Nature Conservancy, 2010; Raisio, 2010; Rep, 2011; Pepsi Co, 2011; Nestlé, 2011; SABMiller et al., 2011; Cooper et al., 2011) and organisations (WWF, 2012) have already begun or are currently moving towards quantifying aspects of their operations related to water, using the water footprint (Water Footprint Network, 2012). In turn, the International Standardization Organization (ISO, 2014) has considered developing a new international standard for water footprinting in order to complement its existing Life Cycle Assessment (LCA) standard (Raimbault and Humbert, 2011).

The origin of the water footprint stems from the concept of "virtual water" coined by Allan (1997, 2001). Also referred

\footnotetext{
${ }^{1}$ Spain (Aldaya et al., 2010b) and Germany (Flachmann et al., 2012) have already began using estimates of water footprints in policy documents, with the Netherlands (Witmer and Cleij, 2012) currently considering this option.
} 
to as "embedded water" or "hidden water", virtual water is the volume of water required to grow, produce and package agricultural commodities and consumer goods; the term "virtual" was preferred as the final product usually contains only a small fraction of water compared to the total volume of water actually used for its production. Allan noticed that rather than importing huge quantities of water to achieve food self-sufficiency, a significant number of water scarce countries in the Middle East were importing grains instead. Building upon the concept of virtual water, Hoekstra and Hung (2002) sought to quantify these "virtual water" flows related to international food trade and thus developed the water footprint concept.

From a production perspective, the water footprint is numerically equal to the virtual water content of a given product or service (Zhang et al., 2012); what distinguishes the water footprint from virtual water is that it is also applied at a consumer level, thus creating a consumption-based indica-

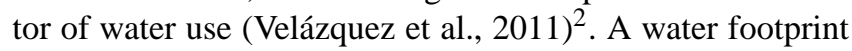
refers to the total volume of freshwater consumed directly and indirectly by a nation or a company, or in the provision of a product or service (Hoekstra and Chapagain, 2006; Hoekstra et al., 2009b). In essence, the additional information provided compared to the traditional, direct water use indicators is that it links human consumption to the space and time of production, accounting for the water use at all the stages along the supply chain of a product. The water footprint concept provides a useful means for estimating flows of water through trade in foodstuffs, and has succeeded in raising public awareness of the already established but somewhat overlooked actuality that the overwhelming majority of global water use takes place in the agricultural sector (Food and Agriculture Organization, 2007). Similarly to virtual water, water footprinting appears to have contributed to moving water issues higher up the political agenda (Wichelns, 2010a).

The water footprint provides a useful means for estimating flows of water through international trade in products and commodities. Trade in foodstuffs has received the most attention since it accounts for the bulk of water trade flows and relates to important national policy issues such as food security. It has been calculated that the Netherlands, for example, has an average water footprint of approximately $37.5 \mathrm{Gm}^{3}$ year $^{-1}$ (or $2300 \mathrm{~m}^{3}$ year $^{-1}$ capita $^{-1}$ ), of which $33.2 \mathrm{Gm}^{3}$ year $^{-1}$ (corresponding to $89 \%$ of the total) is imported into the country in the form of "virtual water" (van Oel et al., 2009). This indicates that the Netherlands is a net virtual water importer. This is also true for other EU countries such as the UK, Germany and Italy,

\footnotetext{
${ }^{2}$ According to the Water Footprint Network (2012), although the "virtual water content of a product" is the same as the "water footprint of a product", the water footprint provides more information with respect to the type of water, as well as where and when that water is being used.
}

all of which import 60-95\% of their total water footprint (Yu et al., 2010; Hoekstra and Mekonnen, 2012b; Tamea et al., 2013) despite none of them being water scarce according to the standard indicator of water scarcity proposed by Falkenmark (Falkenmark, 1986; Seckler et al., 1998). Water footprinting also confirms that meat and dairy products are usually associated with much greater water use compared to plant products because of the large amounts of feed crops, drinking water and service water required by the animals (Hoekstra and Hung, 2002). A recent study also shows the enormous variation in water use efficiencies between different animal production systems around the world (Gerbens-Leenes et al., 2013). This is exemplified by the water footprint of beef $\left(15,415 \mathrm{~m}^{3}\right.$ ton $\left.^{-1}\right)$ (Mekonnen and Hoekstra, 2012a), which clearly dwarfs the average water footprints of most plant products such as tomatoes $\left(214 \mathrm{~m}^{3}\right.$ ton $\left.^{-1}\right)$, wheat $\left(1827 \mathrm{~m}^{3}\right.$ ton $\left.^{-1}\right)$ and soya beans $\left(2145 \mathrm{~m}^{3}\right.$ ton $\left.^{-1}\right)$ (Mekonnen and Hoekstra, 2011b) (see Fig. 1).

Despite the growing enthusiasm for the development and use of water footprints, several researchers have raised significant concerns with respect to the concept and its usefulness, both as a policy tool, as it does not provide sufficient information on the opportunity cost of water, and as an indicator of sustainability and environmental impact (Wichelns, 2011a, 2010b; Gawel and Bernsen, 2011b, a; Perry, 2014). Furthermore, the wide spectrum of methodological approaches currently employed in different sectors and spatiotemporal scales can potentially result in large discrepancies between estimates, creating some understandable scepticism and hesitance when it comes to interpreting the meaning and relevance of different water footprint estimates.

This review firstly considers the importance of methodological differences such as the overall approach (bottomup or top-down) to water footprinting, stand-alone or embedded in LCA, choice of spatiotemporal scale of analysis, along with their repercussions on the validity and credibility of water footprint results. The review then critically evaluates its usefulness for informing policymakers and consumers by considering the arguments that have been put forward in relation to the concept. The review concludes with an appraisal of the current strengths of recent studies and possible present and future options available to researchers, policy-makers, corporations and consumers.

\section{Water footprinting methodologies - still a work in progress}

\subsection{Bottom-up vs. top-down}

The first conceptual issue and decision that needs to be made when calculating water footprints, has to do with the overall scope of the analysis. Both bottom-up and top-down approaches are used to calculate a nation's water footprint 


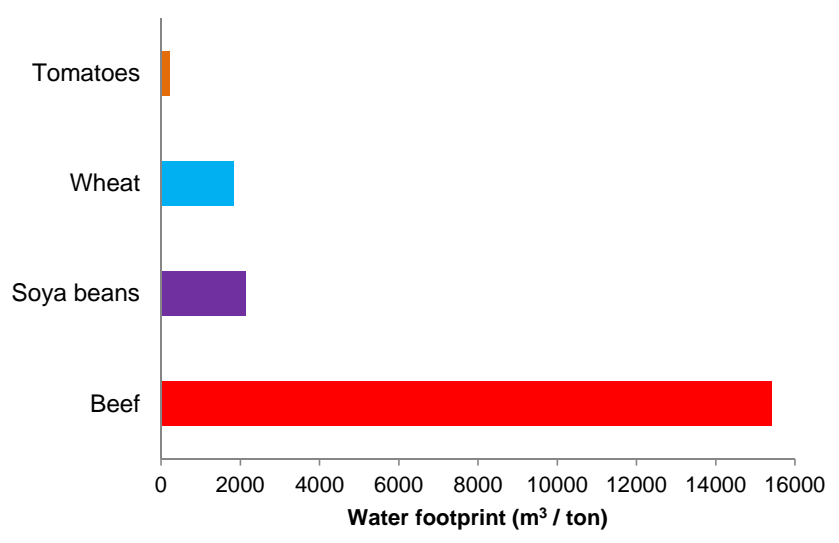

Figure 1. The water footprint of selected agricultural products. Data source: Mekonnen and Hoekstra (2012a). Note that these are average global values which show considerable variability from place to place depending on climate and agricultural efficiency (Hoekstra and Chapagain, 2008).

(van Oel et al., 2009). The top-down approach for assessing a water footprint is to take the total water use in a country and then add any "virtual water" imports and subtract exports. It is based upon environmental input-output analysis (Leontief, 1970; Munksgaard et al., 2005) and uses data on sectoral water use (within countries), inter-sectoral monetary transactions (from national accounts) and trade between countries or regions. Several recent studies appear to favour this approach (Zhang and Anadon, 2014; Cazcarro et al., 2014; Wang et al., 2013). The bottom-up approach was the first to be applied in water footprinting, and is still considered as the more conventional of the two. It sums the water used to make the full range of final consumer goods and services consumed in a country, adding up the water use at each stage of the supply chain for each product. Where primary products are processed into more than one product, the water footprint is attributed according to product and value fractions of the derived products so as to ensure that there is no double counting of water footprints (Chapagain and Hoekstra, 2004; Feng et al., 2011).

The two approaches have their respective merits and weaknesses. The bottom-up approach is more widely used due to its relative simplicity (providing more intuitive commodity information) and its increased level of stability (van Oel et al., 2009) (mainly because of a better availability of the necessary data). Being process based, the bottom-up approach better captures the direct water use of specific agricultural products, while the top-down approach, that relies on highly aggregated sectoral water use figures, captures entire supply chains and as such can better produce detailed water footprints of industrial products (Feng et al., 2011). The two approaches give significantly different results due to the different computational methods as well as the definitions adopted regarding the sectoral origins of output products. Feng et al. (2011) for example show that for eight key water- consuming economies (Australia, China, Japan, US, Brazil, Germany, Russia and South Africa), the estimated total water footprints between bottom-up and top-down methodologies vary substantially, despite the fact that both methods were compared using the same input data set. More recently, Chen and Chen (2013) acknowledge the fact that their topdown study obtained significantly smaller global and national water footprints compared to the bottom-up studies of Hoekstra and Chapagain (2006) and Mekonnen and Hoekstra (2011a). Furthermore, the Chen and Chen (2013) study unsurprisingly estimates higher water footprints for processed food, industrial products and services (65\% of total) compared to agricultural products (35\% of total), owing to its input-output (top-down) approach. A summary of key contributions in the literature to the development of the bottomup, top-down and other water footprint methodologies is given in Table 1.

\subsection{Water "colours"}

Due to the differing environmental impacts and opportunity costs of the various forms of water use, the total water footprint at a national or product level is broken down into subcategories of blue, green and grey water. Blue water refers to the consumptive volume of surface and groundwater ${ }^{3}$ used during the production process. The blue water footprint differs from the more traditionally used water withdrawal volume in the sense that it factors in possible return flows, which refer to the volume of water returned to the water body following irrigation. A comprehensive definition of the blue water footprint is that it includes all irrigation water and any direct water use in industry or in households, minus return flows (Chapagain and Tickner, 2012). Green water resources have been formally defined as the infiltrated rainfall in the unsaturated soil layer (Falkenmark et al., 2009). The green water footprint therefore refers to the precipitation consumed by a crop through evapotranspiration of moisture stored in the soil (also known as effective or productive precipitation) (Mekonnen and Hoekstra, 2011b), thus constituting the rainfed component of the water footprint. The grey component of a water footprint is defined as the volume of freshwater required in receiving water bodies for the assimilation of any pollutant resulting from production so that acceptable water quality standards are met (Mekonnen and Hoekstra, 2011b). Thus, the grey water footprint is an estimated measure of the potential water quality impairment caused by the production of a certain good or service. By including all three components, the water footprint aspires to encompass all kinds of direct and indirect consumptive (blue and green) water use and pollution assimilation (through grey water estimates).

Blue and green water footprints are calculated by multiplying the modelled volume of blue and green water use

\footnotetext{
${ }^{3}$ This includes the use of any kind of groundwater irrespective of its recharge rate.
} 


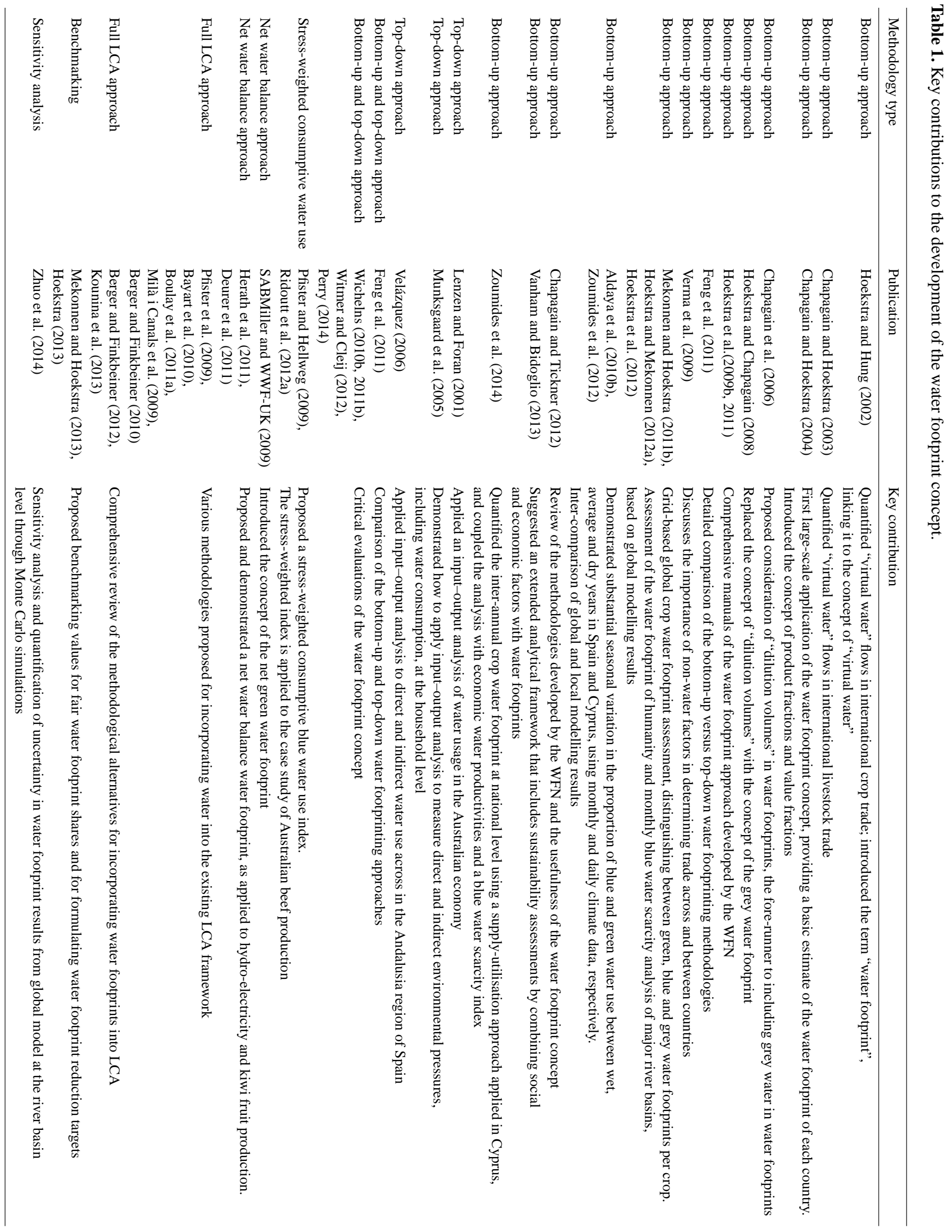


$\left(\mathrm{m}^{3}\right.$ output unit $\left.{ }^{-1}\right)$ by the quantity of production (total output). In this way, any rainfall used in situ by the crop (green water) is distinguished within the water footprint of a product, as well as the volume of irrigation (blue) water assumed to be applied to each crop. The grey water footprint is an estimate of the amount of water needed to assimilate nutrients in agricultural runoff, generally calculated by assuming that $10 \%$ of all nitrogen fertiliser applied to a crop is lost via leaching, and taking the average nitrogen application rate by crop in the country being assessed; the assumed fraction of nitrogen leachate is then divided by the maximum acceptable concentration of nitrogen in the receiving water body. The consideration of grey water is relatively new in water footprinting and was not included in earlier water footprinting studies, such as Chapagain and Hoekstra (2004); it was introduced by Chapagain et al. (2006) using the term "dilution water" which later evolved into the concept of grey water.

There is no doubt that the breakdown of a water footprint into sub-categories provides more information than a footprint consisting of a single number. For example, the estimated global average water footprint for wheat $\left(1827 \mathrm{~m}^{3}\right.$ ton $\left.^{-1}\right)$ breaks down to a green water footprint of $1277 \mathrm{~m}^{3}$ ton $^{-1}$, a blue water footprint of $342 \mathrm{~m}^{3}$ ton $^{-1}$ and a grey water footprint of $207 \mathrm{~m}^{3}$ ton $^{-1}$. Crops frequently grown using irrigation will have higher average blue water footprints than crops that are largely rainfed.

Some crops, an example of which is rice, vary significantly between countries in the mix of water types used. In the Philippines green water makes up $63 \%$ of the water footprint of rice whereas in Pakistan blue water makes up $82 \%$ of the water footprint (Chapagain and Hoekstra, 2011); in this case, the higher blue water component per unit of output in Pakistan can be explained by the greater use of irrigation compared to the Philippines. According to Vanham and Bidoglio (2013), rainfed agriculture is globally the largest productive green water user as only a small share of green water is utilised in irrigated crop systems, whereas irrigated agriculture is globally the largest blue water using sector (the others being industry and households). The blue/green/grey distinction can be used in a similar way to disaggregate national water footprints into their component colours (Fig. 2).

The scientific validity of breaking down a water footprint into its three different "colours" or constituents has been questioned, however, on the grounds that blue and green water are not necessarily discrete categories (Wichelns, 2011a), while grey water is essentially a fictional measure of water pollution that does not reflect either a consumptive use of water or pollution treatment costs (Gawel and Bernsen, 2011b). Witmer and Cleij (Witmer and Cleij, 2012) indeed argue that the three water "colours" are incompatible as blue and green water are resource use (pressure) indicators while grey water is an environmental impact indicator. Furthermore, the inclusion of green water creates inconsistencies between water content figures for agricultural products compared to non-agricultural products (Zhang et al., 2011). This

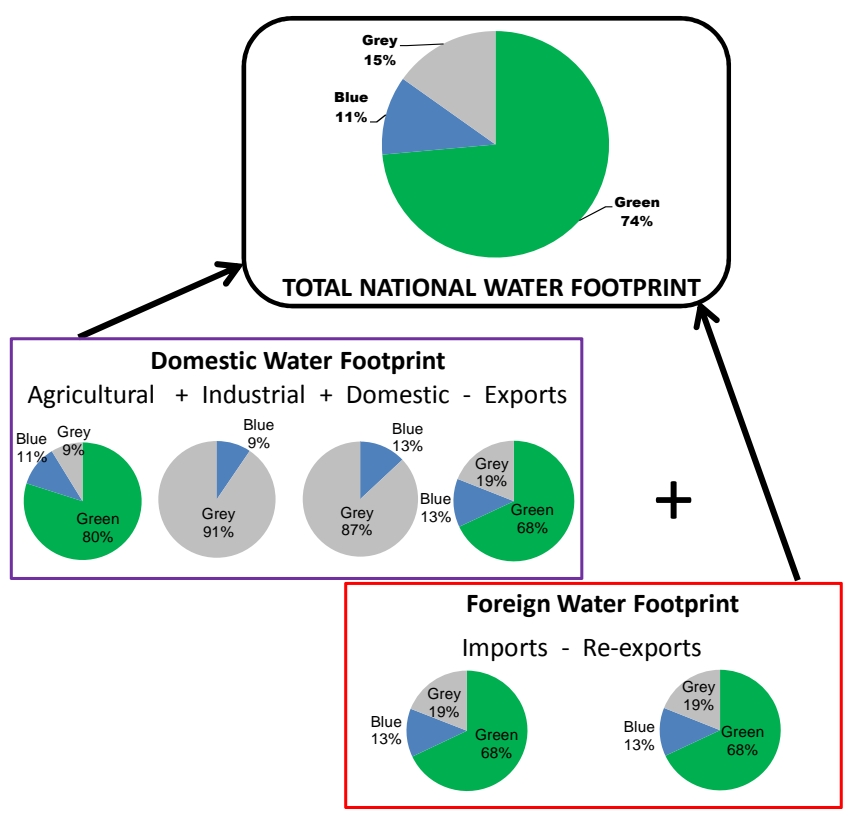

Figure 2. The composition of a national water footprint. It is composed of domestic goods and services plus imports (incoming water) minus exports (outgoing water). Each of these has green/blue/grey components. Data are from Hoekstra and Mekonnen (2012b) and show global averages to illustrate differences in water composition.

is because, whereas in agriculture blue and green water can be substituted and both have a certain opportunity cost, this does not apply to products which do not receive agricultural inputs and as such have no green water component.

With regard to grey water, the consensus among water experts and policymakers is that it is the least meaningful of the three water types as it is a theoretical rather than an actual measured volume (Morrison et al., 2010). It is extremely difficult to determine how much freshwater will be contaminated by polluted water, with the actual extent being dependent upon local hydrology and water quality standards (Nazer et al., 2008). In the global water footprint assessments, grey water quantification is only associated with nitrogen leaching but in many areas other leached nutrients can be the major pollution threat for water quality (Juntunen et al., 2002; Johnston and Dawson, 2005). However, these nutrients are not usually considered in water footprint assessments even though their inclusion has been discussed conceptually in the WFN manual (Hoekstra et al., 2009b) and in Franke et al. (2013). Furthermore, the grey water concept does not provide any information with respect to the impact of polluted water on downstream ecosystem service delivery (Launiainen et al., 2014). Given the fundamental criticisms which exist with respect to the grey water footprint component in addition to the fact that it is not a consumptive use, water quality is best quantified through other means such as water quality modelling (Thomann and Mueller, 1987) or LCA (reviewed in the following sections). 


\subsection{Attempts to estimate impacts of water use - stand-alone impact-oriented approaches}

Within the bottom-up family of approaches, and in addition to the original method proposed by the WFN, there are currently several published methods. Some of these simply elaborate the WFN method whereas others critically argue for omitting or adding certain elements in order to enhance its potential as an impact indicator. Furthermore, some of these methods are proposed as stand-alone procedures (even though some use LCA software) whereas others are designed to be part of a broader and more comprehensive LCA (Berger and Finkbeiner, 2012). This section reviews several of the most important stand-alone alternatives whereas the next section examines full-blown LCA-oriented approaches.

Sausse (2011) notes that certain studies (e.g. GerbensLeenes et al., 2009) define the three water footprint components, but omit this distinction in the quantification process, which limits the clarity and usefulness of the concept. Ridoutt and Pfister (2010a) argue that green water should not be included in water footprints since it does not contribute to water scarcity from a water management perspective - green water neither contributes to environmental flows nor is accessible for other productive uses. Rather, since green water is only accessible through the occupation of land it is better considered as an impact of land use within an environmental LCA rather than through water footprinting. In contrast, many authors still argue that green water resources are also limited, scarce and highly variable, and can be substituted by blue water as well as, in the case of agriculture, act as a substitute for blue water (Jefferies et al., 2012), especially in areas where blue water resources are scarce. According to Berger and Finkbeiner (2012), the actual question to be addressed is how the green water footprint affects blue water availability ${ }^{4}$.

The revised water footprint methodology developed by Ridoutt et al. (2012a) and Pfister and Hellweg (2009) considers only consumptive water use, using a stress-weighted blue water footprint calculated by multiplying the blue water footprint at each point of a product's life cycle by a geographically specific indicator of water stress. Using this methodology for six different beef production systems in Australia, Ridoutt et al. (2012a) estimate water footprints ranging from 3.3 to $221 \mathrm{~m}^{3}$ ton $^{-1}$ of beef (illustrated in Fig. 3). This compares to the global weighted average water footprint calculated by Mekonnen and Hoekstra (2012a) of $15415 \mathrm{~m}^{3}$ ton $^{-1}$, with the difference largely due to Ridoutt et al.'s (2012a) exclusion of green water and grey water. Ridoutt et al. (2012b) estimate a similarly low water foot-

\footnotetext{
${ }^{4}$ In the case of managed forests in Fennoscandian forests, Launiainen et al. (2014) have shown that there is no evidence of forest management having had any effects on evapotranspiration or blue water availability. Nevertheless, this is a context- and climatically specific finding which may differ in other environments.
}

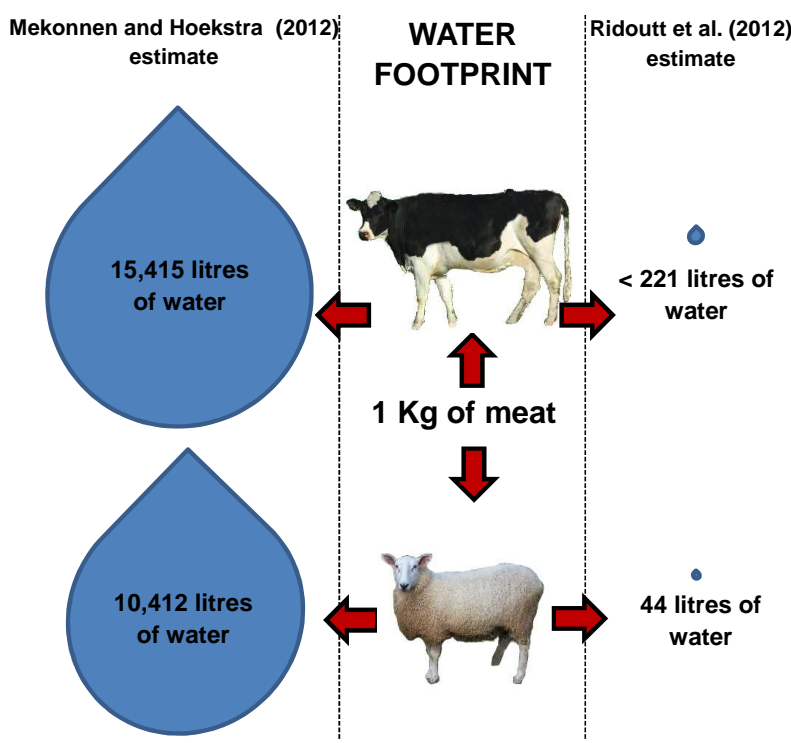

Figure 3. A comparison of the water footprints for beef and lamb calculated by Mekonnen and Hoekstra (2012a) and Ridoutt et al. (2012a, b), illustrating clearly how different methodological approaches for calculating a water footprint can produce starkly different results.

print when they calculate the water footprint of lamb, estimating a footprint of $44 \mathrm{~m}^{3}$ ton $^{-1}$, compared to the estimate $10412 \mathrm{~m}^{3}$ ton $^{-1}$ for lamb of Mekonnen and Hoekstra (2012a) (Fig. 3).

Ridoutt et al.'s (2012a) proposed method accounts, in part, for the opportunity cost of water in different destinations by showing how improved knowledge of water scarcity in different locations has the potential to lead to selective procurement and better choices (Ridoutt et al., 2012a). The Water Footprint Network (WFN), led by A. Hoekstra and colleagues, is opposed to the use of a stress-weighted water footprint on the grounds that calculated weighted figures no longer represent real volumes (Morrison et al., 2010), and do not make sense from a water resources management perspective (Hoekstra et al., 2009c). Using a similar logic, it is debatable, however, whether green and grey water can, in fact, be viewed as real volumes. Hoekstra and Mekonnen (2012a) have recently reiterated their opposition to the concept of a weighted water footprint, arguing that it may lead to an over-emphasis on reducing water use in water-stressed catchments, thus preventing investment in improved efficiency in water-abundant areas. Their idea of promoting global water savings is attractive and ambitious. Nonetheless, an environmental indicator must still account for the fact that water use in a region of water abundance does not impact human wellbeing and ecosystem health to the same extent as water use in a region where water is scarce (Ridoutt and Huang, 2012; Guieysse et al., 2013). This relates to the need of capturing the local opportunity cost associated with the use of a certain volume of water (detailed in Sects. 3.1 and 3.2). 
Large differences in estimated water footprints frequently occur, even with relatively minor differences in methodological approaches. Some companies are recently employing the concept of "net green water" which refers to the difference between water evaporated from crops and the water that would have evaporated from natural vegetation (SABMiller and WWF-UK, 2009; Vanham and Bidoglio, 2013). The use of this metric could well lead to negative water footprints in certain cases. A common example is where farming activities have replaced a pre-existing forested catchment. In this case the removal of trees leads to a decrease in evapotranspiration, resulting in more soil moisture availability as well as more blue water in the form of surface runoff to rivers and aquifer recharge (Ruprecht and Schofield, 1989).

Herath et al. (2011) compare three methods of calculating the water footprint of hydroelectricity: (a) consumptive water use whereby the volume of water evaporated from a reservoir is divided by the energy produced by its hydropower plant, (b) net consumptive use whereby land use changes resulting from the construction of the dam are considered and thus evapotranspiration that would have occurred from the vegetation which the dam replaced is subtracted from the evaporative water losses, and (c) net water balance whereby both water inputs and outputs from the reservoir are considered and thus the volume of precipitation occurring over the reservoir is subtracted from the evaporative water losses from the reservoir. Approach (a) is the approach suggested by Mekonnen and Hoekstra (2012b). Approaches (b) and (c) are alternative variants of the "net green" approach. The results demonstrate the considerable range in water footprint values depending on the method: approach (a) produces an average water footprint for New Zealand hydro-electric reservoirs of $6.05 \mathrm{~m}^{3} \mathrm{GJ}^{-1}$, method (b) $2.72 \mathrm{~m}^{3} \mathrm{GJ}^{-1}$ and method (c) $1.55 \mathrm{~m}^{3} \mathrm{GJ}^{-1}$. Deurer et al. (2011) similarly estimate the "net blue water" footprint of kiwi fruit production by calculating the net aquifer recharge occurring beneath kiwi orchards. They subsequently compare this with the water footprinting methodology proposed by Hoekstra et al. (2009b), which estimates total water consumed during production. The net blue water footprint averaged $-500 \mathrm{~L} \mathrm{tray}^{-15}$ of kiwi fruit whereas the blue water footprint using the Hoekstra et al. (2009b) methodology was $100 \mathrm{Ltray}^{-1}$. Deurer et al. (2011) found that kiwi fruit production had no impact on freshwater scarcity in soils and thus questioned the usefulness of the green water footprint concept.

Although the methodological possibilities for stand-alone measures are numerous depending on the context, there is as yet no established method that stands out as a gold standard. To a certain extent, the appropriate methodology for a water footprint study should depend on what goal it is trying to achieve (Chapagain and Tickner, 2012; Jefferies et al.,

\footnotetext{
${ }^{5} \mathrm{~A}$ tray is defined by the authors as $3.6 \mathrm{~kg}$ of fresh produce, and is the standard functional unit of productivity in the New Zealand kiwi fruit industry (Deurer et al., 2011).
}

2012). However, the diversity of approaches, with their dramatically different results, means that the outcomes of studies performed by different researchers or organisations may not be compatible. In some cases there may even be a risk of biased outcomes since researchers are more likely to choose the methodology which best gives the desired result.

\subsection{Attempts to estimate impacts of water use - full-blown LCA approaches}

Despite the primary aim of this review being to concentrate on the usefulness of stand-alone procedures, the voluminous LCA literature also demands some attention. In an attempt to provide water footprint methods with an improved ability to quantify environmental impact and to complement existing LCA methodologies, several studies have been published in recent years proposing various ways to integrate water footprints into LCA inventories (Pfister et al., 2009; Bayart et al., 2010; Boulay et al., 2011a; Milà i Canals et al., 2009; Berger and Finkbeiner, 2010). LCA, a technique which originates from the field of industrial ecology, is a tool capable of measuring the combined effect of several environmental impacts of products across their supply chain (from cradle to grave) (Finnveden et al., 2009). LCA did not traditionally include water consumption (freshwater use) as an impact (Milà i Canals et al., 2009), hence the process of integrating water footprinting into LCA is still relatively new and the procedures far from clear-cut, which is, perhaps, a reflection of the state of the concept in general.

Several comprehensive reviews of methodological alternatives and developments by different working groups are available in the LCA literature (Berger and Finkbeiner, 2010, 2012; Kounina et al., 2013). According to Kounina et al. (2013) there is no single method which comprehensively describes all potential impacts derived from freshwater use. Approaches differ significantly in terms of considered water types, whether or not they account for local water scarcity and differentiation between watercourses and quality aspects (Berger and Finkbeiner, 2010). Some LCA applications also explicitly quantify potential health impacts (Boulay et al., 2011b; Motoshita et al., 2011), ecosystem impacts (Milà i Canals et al., 2009; Pfister et al., 2009), and resource depletion impacts (Milà i Canals et al., 2009; Pfister et al., 2009) whereas others do not. Approaches focusing on comprehensive water quality assessment also exist which consider the potential water use impacts caused by a loss of functionality (due to water quality impairment) for human users (Boulay et al., 2011a). Important dilemmas also exist with respect to whether the final impact category indicator will be chosen at midpoint (problem-oriented with more specific scientific focus) or endpoint (damage-oriented, which is easier for consumers to understand) (Kounina et al., 2013) and with respect to which scarcity indicator to use in order to account for local water scarcity (Berger and Finkbeiner, 2012). 
A lengthy discussion of the aforementioned and other technical discrepancies is beyond the scope of this review but what becomes clear is that there is still only preliminary scientific consensus with respect to the parameters to consider as well as the methodology to account for water use-related impacts (Núñez et al., 2012). Moreover, as with stand-alone approaches, different methods produce a range of results. Most authors agree that there are certainly advantages to incorporating water footprints into the more comprehensive and tested environmental assessment tool that is LCA (Buckley et al., 2011), the most important being that water use impacts of interest can be comprehensively quantified as impact-oriented indicators (Berger and Finkbeiner, 2012). Recently, some authors have introduced a promising stand-alone LCA-based procedure (Ridoutt and Pfister, 2013) which provides another option and yet another possibility, however.

Other authors maintain that LCA and conventional water footprints are useful for different purposes (Jefferies et al., 2012). Their main argument is that the volumetric water footprint approach as defined by the WFN is effective in describing the local and temporal nature of water-related impacts, with its focus being on the components at the different locations as opposed to the final number. Nevertheless, the problem is that this creates the need for interpretation of the separate components of the water footprint which in an impact-oriented LCA approach would be combined into a final impact indicator. An LCA-derived final impact indicator does require more intricate modelling and calculation but produces a result which tends to be easier to comprehend for consumers and business.

\subsection{Choice of spatiotemporal scale of analysis}

According to Hoekstra et al. (2011), there are three major levels where water footprint analysis can be applied, namely global, national/regional and local/corporate level. For each of these spatial applications, there are different temporal explications regarding the data requirements, ranging from mean annual data in the case of global assessments, to daily data in the case of location or corporate specific case studies. Because of these spatiotemporal differences regarding the modelling of input data, the results provided often have different end uses. On the one hand, global studies provide static or average results that crudely capture different components of national or crop-specific water footprints. For this reason, global studies (Hoekstra and Mekonnen, 2012b; Chapagain and Hoekstra, 2004; Mekonnen and Hoekstra, 2010b) are not appropriate for policy formulation; as such, they can only be used for comparative purposes in order to raise public awareness with regards to agricultural water use, or for developing projections for future water consumption levels at a global level.

The results of global assessments are typically used to quantify the virtual water flows related to food trade (van Oel et al., 2009; Yu et al., 2010; Hoekstra and Mekonnen, 2012b). On the other hand, local-specific assessments rely on spatial and temporally explicit data, and can potentially provide more relevant results for local policy formulation. For example, Aldaya et al. (2010b) analysed the crop production water footprint of the Mancha Occidental Region in Spain using monthly average climate data for three distinct years (dry, average and humid). The study revealed that the share of green and blue crop water footprints for typical crops grown in the region can vary substantially between seasons.

Another example is a spatiotemporally explicit soil water balance model for the island of Cyprus (Zoumides et al., 2012, 2013). The model used daily climatic data and community-level land use data for the period 1995-2009. The results of this model were compared with previous global water use assessments of Siebert and Döll (2010) and Mekonnen and Hoekstra (2010a, 2011b) for Cyprus, to reveal the large discrepancies among estimates. In particular, the Siebert and Döll (2010) estimates for Cyprus were $72 \%$ lower for total green water use and $41 \%$ higher for blue water use for the period 1998-2002, while the Mekonnen and Hoekstra (2011b) average estimates for the period 19962005 were $43 \%$ higher for blue water use and almost identical for green water use. These differences in modelling outcomes are attributed both to different climate and land use data sets, but also to different modelling parameters, such as planting and harvesting dates, soil and other parameters.

The differences between global and local model estimates indicate one of the key issues regarding the credibility and usefulness of the water footprint as environmental impact indicator. Finger (2013) has recently argued that the mean global crop water footprint values that are most frequently cited are not informative enough. This mainly relates to the fact that the spatial heterogeneity in terms of both climate parameters and production systems is poorly captured and reported. Furthermore, although the limitations of global water footprint assessments are usually included in academic reports, they are not stressed to the same extent when these mean global values are reported in the media or forwarded to policy makers. A recent example is the attempt by the Federal Statistical Office of Germany to establish water footprint accounts of food products in the country, for the period 2000-2010 (Flachmann et al., 2012). Although the input statistics are directly derived from the national food-related accounts of Germany, the water footprint values per crop and per country are from the global water footprint assessment of Mekonnen and Hoekstra (2011b).

Similarly, global estimates have been recently employed to assess the sustainability of consumption in France (Ercin et al., 2013), and to quantify the impact of the cut flower trade in Lake Naivasha basin (Kenya) (Mekonnen et al., 2012); the latter is going one step further and proposes a water sustainability premium to fund water use efficiency measures, even though the limitations of global water footprint estimates is acknowledged. In the absence of temporally explicit analysis 
using location-specific data as well as calibration and validation of model parameters with field data, such studies can potentially result in false estimates and provide the wrong indication both to policy makers and the general public regarding the internal and external water footprint, and the blue and green water components of production and consumption within a country or region. The same limitation also applies for product-specific water footprint assessments that rely on global water use model estimates (Mekonnen and Hoekstra, 2010b; Van Oel and Hoekstra, 2012; Ercin et al., 2011). Additional development is required if water footprints are going to be used for sustainability assessments, as the social and economic components require further development and testing (Vanham and Bidoglio, 2013). However, it is in sustainability assessments and the identification of specific unsustainable hot spots in a supply chain which Witmer and Cleij (2012) see as among the major uses of water footprints.

The choice of spatiotemporal scale should depend on what the study is trying to achieve. Using global averages taken from the WFN for a locally specific application is certainly not advisable and is likely to result in erroneous estimations of local water use impacts. This is particularly relevant to businesses wishing to engage in transparent water use estimates across product supply chains, with potential benefits to both their own interests (saving water and reducing costs) as well as for better informing customers. Many companies and corporations have already embraced water footprinting of their operations (Unilever, 2012; Coca-Cola and Nature Conservancy, 2010; Raisio, 2010; Rep, 2011; Pepsi Co, 2011; Nestlé, 2011; SABMiller et al., 2011; Cooper et al., 2011; Ruini et al., 2013; Francke and Castro, 2013).

Nevertheless, it would appear that most studies do not use their own spatially and temporally explicit water footprint values and are potentially basing the analysis of their own operations on previously published global values. Herein lies one of the dangers with conventional water footprints. A company or institution wishing to quantify the water embedded in its supply chain must carry out its own estimates of water use at different stages of production and also engage with all its suppliers in order to acquire the most representative water use data for all inputs to production. Making use of existing global figures from the WFN or other figures calculated in previous studies is unlikely to provide an insightful metric of water use impact along a specific supply chain or lead to reliable environmental hotspot identification (see Sect. 3.2).

\section{Uses of water footprints}

Despite the growing interest in water footprinting and the continuing refinements and comparisons of alternative methodologies, there has been relatively little critical discussion about the purpose or the uses of water footprints, with only a handful of papers questioning its purpose. Uses of water footprinting suggested by those developing the water footprinting methodologies can be grouped under three broad themes: (i) a tool for assisting water resources management and dealing with water scarcity; (ii) a means of consumer empowerment; and (iii) a way of promoting equity in the use of global water resources.

\subsection{A tool for assisting water resources management and managing water scarcity at national/regional/corporate level}

Water footprinting is put forward as a tool for assisting policy development in the water sector by showing the extent of interdependence of individual countries on the water resources of other countries (Chapagain et al., 2006) and thus allowing countries to assess their national food security and develop environmental policy (Hoekstra and Mekonnen, 2012b). The ability to quantify in simple terms the hydrological interdependencies at the national level is one of the strengths of water footprinting, as prior to the development of water footprints such an indicator was lacking.

It has been suggested that water footprinting can help governments understand the extent to which the size of their national water footprint is due to consumption patterns or inefficient production and thus to prioritise policy actions such as changing consumption patterns or improving the water efficiency of production (Hoekstra and Mekonnen, 2012b; Hoekstra and Chapagain, 2007; Aldaya et al., 2010a; Flachmann et al., 2012). Similarly, water footprinting has been proposed as a tool for exploring whether production sites are suitable for producing crops for export (Chapagain and Orr, 2009; Mekonnen et al., 2012). It has also been suggested as a means to assist corporations improve their efficiency of production and minimise water-related business risk by identifying any components of their supply chain which are vulnerable (Coca-Cola and Nature Conservancy, 2010; Ercin et al., 2011). However, by adopting an entirely water-centric approach, other factors, like the livelihoods of those working in agriculture, are largely ignored (Mostert and Raadgever, 2008). It has been argued, for instance, that the main purpose of trade worldwide is not necessarily to reduce the demand for scarce production inputs but to enhance incomes and well-being, especially when the net benefit of such a policy to the local environment or society is uncertain or poorly justified (Wichelns, 2010b). While water is clearly an input to production, it cannot be the sole criterion for judging the rationality of trading patterns, as trade between countries is determined by a variety of factors such as land, labour, technology, trade agreements and other factors (Aldaya et al., 2010b; Verma et al., 2009).

Some water footprinting researchers have suggested in a policy context that water footprinting can be used to show countries how to externalise their water demands and thus save water (Hoekstra, 2009; Hoekstra et al., 2009a; Aldaya et al., 2010b; Biewald, 2011; Biewald and Rolinski, 2012), 
with the dominant argument being that water-scarce countries should aim at importing water-intensive products from humid countries with abundant water resources. Conceptually, however, it is difficult to see how a water-scarce country can save through international trade something which it never had, and some countries are shown to have saved through food imports more water than they have available locally (Wichelns, 2010b, 2011b). Antonelli et al. (2012) strongly criticise the concept of "savings", particularly in the case of green water, which is trapped in the soil and cannot possibly be diverted to non-agricultural uses.

Suggesting that a country "loses" water by exporting goods from employment- and wealth-generating industries is also conceptually problematic. While countries need to ensure that water is allocated in ways that reflect its scarcity and its opportunity cost, water footprinting does not assess the opportunity cost of water (Wichelns, 2010b). Furthermore, there is no consideration of the important concept of economic water productivity in a basic water footprint (Gleick, 2003). However, water footprints do allow comparisons of economic productivity if results are linked to the gross value added per unit of water used in addition to just product yields per unit of water (Aldaya et al., 2010b). Economic water productivity (usually measured in dollars per unit of water), implies that any comparisons of volumes of water used in the making of agricultural or industrial products must also account for (at least) the economic yield of the water used.

Dividing water footprints into blue, green and grey water footprints has been suggested by Mekonnen and Hoekstra (2010b) as a means to identify ways of saving blue water, which is seen as having a higher opportunity cost than green water. However, the opportunity cost of water use is locationspecific: high value rain-fed agricultural land may be scarce in a region where blue water is not scarce, thus blue water will not always have a higher opportunity cost than green water. For example, in the Netherlands $8.7 \%$ of total renewable (blue) water resources are withdrawn each year, suggesting that blue water is not particularly scarce, but arable land is obviously a limited resource (FAO, 2009). This comes back to the argument with respect to the usefulness of the green water concept. Where there is no apparent impact of any green water use on surface or groundwater, its use impact is essentially a land use impact and so should be considered as such via LCA rather than through water footprints.

Water footprints have been suggested as a means to encourage improved agricultural water efficiency throughout the world. Nevertheless, improving irrigation efficiency does not necessarily save water at the basin scale as it may reduce valuable return flows and limit aquifer recharge (Ward and Pulido-Velazquez, 2008). Watersheds differ with respect to their physical and institutional characteristics, meaning that decisions to achieve more efficient water use are best taken at the water-basin scale, as advocated by more traditional water resources management perspectives (Mitchell, 1990; Bach et al., 2011; Gooch and Stalnacke, 2010). It is along these lines that some of the recent developments in water footprints have occurred whereby monthly or daily climatic variables have been combined with annual land use and crop production to obtain location- and time-specific water footprints (Aldaya et al., 2010b; Zoumides et al., 2014).

While such developments of the water footprint concept make the results more accurate (rather than just being global averages), policy makers and the media are attracted to the big simple numbers derived from global studies which have little relevance for local water resources management or policy making. As the methodology and results of water footprint analysis becomes more spatially and temporally specific and thus sophisticated, it loses its major strength - an indicator that simplifies complicated data down to a form which is conceptually simple and readily understood. The further water footprints move in this direction, the further they get from their starting point of quantifying the volumes of "virtual water" being traded between countries and their role as a consumer indicator, thus becoming simply another form of local hydrological assessment.

The water footprint is a useful indicator for highlighting in simple terms global or regional hydrological interdependences and drawing attention to water issues but in its basic form its simplicity restricts its usefulness for local water management or policy making while enhancing the indicator to overcome this problem means losing the simplicity.

\subsection{A means of consumer empowerment}

Water footprinting at the product level has been suggested as a means of empowering consumers by providing information to allow them to take responsibility for the impact of their consumption (Ridoutt and Pfister, 2010b; Hoekstra and Mekonnen, 2012b; Feng et al., 2012). According to its proponents, by empowering the final consumers of products, a tool like water footprinting can extend water management beyond single catchments or countries (Chapagain et al., 2006), thus providing a means to overcome the inadequacies of water governance found in some countries (Ridoutt and Pfister, 2010b).

The extent to which consumer choices in one country can modify water policy decisions elsewhere in the world is debatable. More fundamentally, it is unclear how water footprinting can empower consumers. A water footprint alone only indicates the volume of water required to produce a product and thus does not provide consumers with information to allow judgement on the sustainability of this water use (Witmer and Cleij, 2012). A water footprint does not provide information on the impact of that water use on the local environment, the opportunity costs of the water used, nor the degree of water scarcity in the producer region. Informing consumers of the environmental impact of the products they consume may potentially be useful, but water footprints do not do this as the information provided, at present, is too aggregated and limited. This may even become misleading, 
when, for the sake of simplicity, only total water footprints of products are reported, with no elaboration on what the figure includes and where it was taken from.

Breaking the footprint down into its constituent components of blue, green and grey waters at the global or national level still does not provide consumers with real information on the opportunity cost of the water or the environmental impact of production, besides the fact that the agricultural stages of production are always shown to account for the majority of water use for all three components. It also means that consumers are no longer being provided with a single indicator but a set of indicators. It instead becomes another composite sustainability indicator complete with value judgements upon which the weighting is based.

As mentioned above, several companies have already made attempts to calculate water footprints of their activities. Most of these companies have embraced the concept of water footprints, seeing them as a natural follow-up to carbon footprints and offering an additional way to render the environmental impact of their supply chains more transparent to consumers. While the credibility of such corporate water footprints can be questioned, as previously discussed, they do appear to force companies to directly consider their use of water in the supply chain and the broader impacts on the aquatic environment. Indeed, Witmer and Cleij (2012) argue that by calculating the water footprint of their supply chains and operations, companies can identify hot spots of environmental impact relating to their water use. Focusing upon these "unsustainable hot spots" they argue would be more beneficial than publishing their overall water footprint in their sustainability report.

Water footprints thus do not provide a means of environmental consumer empowerment but through their calculation water footprints may focus corporate attention on the water use of their operations. This may lead corporations to start considering inefficient or unsustainable water use even if a conventional water footprint assessment does not explicitly identify inefficient or unsustainable water use.

\subsection{A way of promoting equity of water use and "virtual water" trade}

By quantifying direct and indirect water use, water footprinting allows the comparison of total per capita water use in different countries where previously it was only possible to compare direct water use and only within national boundaries. The inclusion of indirect and external water use allows consideration of the equity and sustainability of consumption (Chapagain et al., 2006). Under current production efficiencies, it is not possible for everyone in the world to develop water footprints equal to those currently achieved in countries with very high water footprints, such as the US (Hoekstra, 2011). Based upon this concept of inequitable water use, Ridoutt and Pfister (2010b) argue that developed countries, through their supply chains, take a disproportion- ate share of the world's water resources, and therefore just as greenhouse gas reduction targets have been set, water footprint reduction targets need to be set. Mekonnen and Hoekstra (2010b) suggest that a water scarcity rent on traded products would be another means of tackling the inequality of water resources use and allow externalities to be passed on to the consumers of products. Hoekstra (2011) advocates for water footprint quotas to be allocated to countries on a per capita basis to ensure that their citizens consume a fair proportion of the world's water resources and thus increase equity in total water use. Furthermore, Hoekstra (2013) and Mekonnen and Hoekstra (2013) suggest that benchmarking values can be used for formulating water footprint reduction targets.

Conversely, it has been argued that the discussion on the equity of water use ignores the fact that water scarcity is a largely local or regional problem where demands on water resources exceed local supplies; if people in one location cut their consumption of water-intensive products it will have little impact on water scarcity in other regions (Wichelns, 2011a). Farmers in the exporting regions would likely adapt by switching to other crops or export markets while carrying on using the water, while water-intensive products being consumed may not originate from water-scarce regions in the first place. Suggesting that people in one location are consuming an unfair amount of water because they consume more than people in another region is unhelpful. People living in humid areas are likely to consume more water than people living in arid areas simply because people tend to make use of the available resources in the area where they live (Wichelns, 2011a). Countries with high total water footprints tend to consume water available from their own territories (Fader et al., 2011), while many of those countries with high external water footprints (such as the Netherlands; van Oel et al., 2009) import goods due to a scarcity of arable land not local water resources (Wichelns, 2010b). To this end, water is just one of the factors influencing a country's comparative advantage when it comes to trade.

Gawel and Bernsen (2013) argue that nearly all "virtual water" trades can be condemned from a certain moral standpoint due to the potential negative consequences for developing countries, and thus attaching moral judgements to water footprints is not helpful. A developed country importing food from a developing country can be accused of externalising the environmental consequences of its water footprint and unfairly taking the water resources of developing countries. A developed country exporting food to a developing country can be accused of creating an unacceptable state of dependency in the importing country; however, a developed country which does not export can be accused of hoarding its water resources or consuming internally more than its "fair share" of global water resources. A developing country importing food can be accused of neglecting its rural economy and allowing itself to become dependent upon others. Lastly, a developing country exporting food can be accused 
of allowing itself to be exploited by developed countries seeking to externalise their water footprints and associated environmental damage (Gawel and Bernsen, 2013). Applying normative criteria to water footprints and associated "virtual water" trading is problematic and suggests that waterrelated problems need to be tackled according to the specifics of their location. Thus, as an indicator for ethical trade or consumption, water footprints are unhelpful.

\section{Water footprinting compared to other "footprint" indicators}

In a globalised world, production and consumption are frequently geographically distant, allowing the outsourcing of high environmental impact activities to less developed countries (Galli et al., 2012). As such, indicators are needed to link consumers to the demands they place on the environment. Water footprinting has been suggested as a complementary indicator to the ecological and carbon footprints, with some researchers already considering grouping the three footprints into a "family" of indicators (Fang et al., 2014; Galli et al., 2012). However, the water footprint is fundamentally different to both the ecological and carbon footprints (Perry, 2014).

The ecological footprint was introduced by Rees (1992) to measure human consumption in terms of land use, with all consumption being converted into a common metric, globalhectares - the land area needed to sustainedly supply the resources used or assimilate the wastes produced. Whereas the ecological footprint considers the land use implications of consumption, the water footprint considers the water use implications of consumption (Hoekstra, 2009).

Meanwhile, carbon footprinting measures the total amount of greenhouse gas emissions which are directly or indirectly caused by a product over its life cycle, with carbon footprints expressed in the common metric of $\mathrm{kg}$ of $\mathrm{CO}_{2}$ equivalent (Galli et al., 2012). Carbon footprinting thus tries to show the impact of consumption decisions for climate change. Ridoutt and Pfister (2010b) argue that, just like carbon footprinting, water footprinting can create pressure for change. They do, though, point out that, unlike in the case of the carbon footprint where several companies and countries have set themselves arbitrary targets, it remains unclear how much reduction in water consumption needs to be achieved at present.

Water footprints, however, are not analogous to either carbon or ecological footprints, as carbon footprints describe impacts in terms of the limited absorptive capacity of the Earth's atmosphere of a consumption output and ecological footprints in terms of the productive and absorptive capacity $^{6}$ of scarce land resources (Wichelns, 2011a; Gawel and Bernsen, 2013). Water footprints in their conventional form

\footnotetext{
${ }^{6}$ The majority (54\%) of the world's ecological footprint, according to the Global Footprint Network, is composed of the land area required to sequester global $\mathrm{CO}_{2}$ emissions (Global Footprint Net-
}

are simply calculations of a single important input used for production or consumption without any accounting of the impacts of use. In the same way that methane and carbon dioxide emissions cannot be compared directly on a kilogram level (because of their very different global warming potential), water consumption in places with different water scarcity levels are not comparable (Berger and Finkbeiner, 2012). Products often have complex, spatially disconnected production chains. This means that simply aggregating all local water consumption determined at catchment or river basin level into one figure is physically incorrect (Launiainen et al., 2014). Although with methodological developments like the inclusion of pollution impacts through grey water footprint accounting there have been attempts to incorporate impacts of use, such innovations move water footprints away from being an actual quantitative measure of water used in production. Furthermore, within LCA, there are still several possible characterisation models available for water consumption whereas an internationally agreed characterisation model for carbon footprinting already exists (Berger and Finkbeiner, 2012).

While water may be scarce in some locations, in many regions it is not. The impacts of water use vary spatially and thus water saved in a water-abundant region will have no effect on abundance in water-scarce regions. Water availability is also subject to significant seasonal and inter-annual variation in certain places, meaning that the impact of water use can vary markedly from one month or one year to the next. A kilogram of carbon dioxide emitted to the atmosphere has the same impact regardless of where or when the emission occurs but the impact on the environment of a litre of water use will vary dramatically.

Contrasting a hypothetical energy footprint with that of a carbon footprint illustrates what is, perhaps, the key shortcoming of water footprints. An energy footprint which involves calculating the total energy input required for producing and supplying a consumer product, would be a poor substitute for the carbon footprint since it would not provide information on the environmental impacts of the energy used. As such, it would provide little useful information to consumers or policy makers. Breaking down energy footprints into subcategories, such as a product's renewable energy and non-renewable energy footprints, along similar lines to which water footprints have been broken down to green, blue and grey water footprints, would still not provide sufficient information to allow useful comparisons of the environmental impact of two products. A carbon footprint, however, while only assessing a single environmental impact the climate change impact - does theoretically provide a metric for direct comparison of two products for the impact on the atmosphere will be the same where ever the carbon emission occurs (Gawel and Bernsen, 2013). Water footprints are

work, 2010). Land required to produce products for consumption thus makes up a minority of humanity's ecological footprint. 
thus fundamentally different to carbon footprints due to the fact that the former focuses upon a production input with localised environmental characteristics while the latter focuses on an output with global environmental impact.

\section{Conclusions: present options and future directions}

In this review we have shown that there is still no consensus with regards to both the methodological standard to be employed for water footprinting as well as the actual purpose behind water footprinting. We believe that these two types of uncertainty (methodological and purpose-related) may be reinforcing each other as part of a vicious cycle. Exhaustive debates with respect to the methodological procedures actually detract from the fact that there are numerous proposed uses of the concept, with no universally defined and agreed purpose. To some extent, the purpose of a water footprint assessment is determined by the spatiotemporal scale of application. For broad scale analysis of water use, water footprinting can provide some useful insight through its aggregation of massive quantities of data into simple figures. For real decision making and policy at the regional and local levels, water footprints have limited use because too much critical information, like the opportunity cost of different water resources, their spatial and temporal dimensions, and the wider socioeconomic and environmental context, are currently missing from most applications and assessments.

The recent global water footprint studies distinguish water use into green, blue and grey water footprint components and attempt to address some of the shortcomings of previous assessments by including environmental flows and monthly variations in water availability (Hoekstra et al., 2012; Hoekstra and Mekonnen, 2012a; Mekonnen and Hoekstra, 2011b). While these revised approaches offer more insight on water-stressed areas compared to worldwide water assessments that do not employ a water footprinting approach (Vörösmarty et al., 2000, 2010; Oki and Kanae, 2006; Döll et al., 2003; Alcamo et al., 2007; Hanasaki et al., 2008), the distinction between different "colours" of water may be debated (based on arguments presented earlier).

In our view, the quantitative components that separate green and blue water are interrelated and their distinction provides further insights. On the other hand, the grey water footprint component is heavily criticised in the literature which implies that it either needs to be abandoned (which would mean that the water footprint concentrates solely on water use without any consideration for water quality) or significantly developed in order to arrive at an accepted methodology. It is also important to consider that both recent and previous global water use assessments rely on broad assumptions with relatively low climate, spatial and temporal resolution data compared to locally specific studies. On the one hand, such global assessments offer the advantage of using dynamic models which can incorporate future climate, popu- lation and economic projections for scenario analysis (Ercin and Hoekstra, 2014). On the other hand, the uncertainties of global assessments are significant and results need to be carefully interpreted, especially when zooming in to specific locations. In essence, much more hydrological modelling precision and socio-economic information is required for formulating such policies, which are currently lacking in water footprint assessments.

When the water footprint framework is applied at regional, river-basin and local levels, model parameters need to be calibrated and validated with field data, and results accompanied by a sensitivity analysis (Bastiaanssen et al., 2007; Zhuo et al., 2014). In addition, blue water footprints need to be distinguished between surface and groundwater resources, as the potential impacts associated with the use of each blue water source can vary considerably at the local scale (Zoumides et al., 2012, 2013; Dumont et al., 2013) Such complex applications, however, are well established in hydrological sciences, which implies that the actual contribution of the water footprint concept to water management policy is rather limited (Perry, 2014).

Despite its methodological limitations, the water footprint has succeeded in stimulating the discussion on the interlinkages between water use, food security and consumption (both in terms of different diet types as well as the increasing quantities of food produced and consumed worldwide) (Hadjikakou et al., 2013; Vanham and Bidoglio, 2013; Cazcarro et al., 2012). The concept has also stimulated increasing attention at the corporate level (Mason, 2013), facilitating companies to begin to consider the environmental impact of their water use. At the present stage of its methodological development, corporate water footprinting is best carried out through incorporating water use into LCA - a more comprehensive tool which does not focus on a single environmental parameter or production input. There are also some emerging stand-alone procedures (Ridoutt and Pfister, 2013) that make use of LCA methodologies.

To conclude, this review has found the water footprint concept to be helpful in terms of highlighting hydrological interdependencies between nations or regions in simple terms (providing a previously unavailable indicator in this respect) and also for identifying hot spots of environmental impact relating to their water use (which can serve as an initial scoping exercise, especially at a corporate level). However, the review has also found the concept to be presently unhelpful as a means of river basin management, consumer empowerment, as an indicator of ethical trade or consumption or as a complementary indicator to go alongside ecological or carbon footprints. 
Acknowledgements. The authors would like to thank the editor, the three anonymous referees, and also Davy Vanham for their valuable review comments.

Edited by: P. van der Zaag

\section{References}

Alcamo, J., Florke, M., and Marker, M.: Future long-term changes in global water resources driven by socio-economic and climatic changes, Hydrolog. Sci. J., 52, 247-275, 2007.

Aldaya, M. M., Garrido, A., Llamas, M. R., Varela-Ortega, C., Novo, P., and Casado, R. R.: Water footprint and virtual water trade in Spain, in: Water Policy in Spain, edited by: Garrido, A. and Llamas, M. R., CRC Press, Leiden, 49-59, 2010a.

Aldaya, M. M., Martinez-Santos, P., and Llamas, M. R.: Incorporating the water footprint and virtual water into policy: Reflections from the Mancha Occidental Region, Spain, Water Resour. Manag., 24, 941-958, 2010b.

Allan, T.: "Virtual Water": A Long Term Solution for Water Short Middle Eastern Economies?, British Association Festival of Science, Water and Development Session - TUE.51, 14.45, University of Leeds, 9 September 19971997.

Allan, T.: The Middle East Water Question: Hydropolitics and the Global Economy, I. B. Tauris, London, 2001.

Antonelli, M., Roson, R., and Sartori, M.: Systemic Input-Output Computation of Green and Blue Virtual Water "Flows" with an Illustration for the Mediterranean Region, Water Resour. Manag., 26, 4133-4146, 2012.

Bastiaanssen, W. G. M., Allen, R. G., Droogers, P., D'urso, G., and Steduto, P.: Twenty-five years modeling irrigated and drained soils: State of the art, Agr. Water Manage., 92, 111-125, 2007.

Bach, H., Clausen, T. J., Trang, D. T., Emerton, L., Facon, T., Hofer, T., Lazarus, K., Muziol, C., Noble, A., Schill, P., Sisouvanh, A., Wensley, C., and Whiting, L.: From local watershed management to integrated river basin management at national and transboundary levels, Mekong River Commission, Vientiane, 2011.

Bayart, J.-B., Bulle, C., Deschênes, L., Margni, M., Pfister, S., Vince, F., and Koehler, A.: A framework for assessing off-stream freshwater use in LCA, Int. J. Life Cycle Ass., 15, 439-453, 2010.

Berger, M. and Finkbeiner, M.: Water Footprinting: How to Address Water Use in Life Cycle Assessment?, Sustainability, 2, 919-944, 2010.

Berger, M. and Finkbeiner, M.: Methodological challenges in volumetric and impact: oriented water footprints, J. Ind. Ecol., 17, 79-89, 2012.

Biewald, A.: Give virtual water a chance! An attempt to rehabilitate the concept, GAIA, 20, 168-170, 2011.

Biewald, A. and Rolinski, S.: The theory of virtual water: Why it can help to understand local water scarcity, GAIA, 21, 88-90, 2012.

Boulay, A.-M., Bouchard, C., Bulle, C., Deschênes, L., and Margni, M.: Categorizing water for LCA inventory, Int. J. Life Cycle Ass., 16, 639-651, 2011a.

Boulay, A.-M., Bulle, C. C., Bayart, J.-B., Deschênes, L., and Margni, M.: Regional characterization of freshwater use in LCA: modeling direct impacts on human health, Environ. Sci. Technol., 45, 8948-8957, 2011b.
Buckley, C., Friedrich, E., and von Blottnitz, H.: Life-cycle assessment in the South African water sector: A review and future challenges, Water SA, 37, 719-726, 2011.

Cazcarro, I., Duarte, R., and Sánchez-Chóliz, J.: Water flows in the Spanish economy: agri-food sectors, trade and households diets in an input-output framework, Environ. Sci. Technol., 46, 65306538, 2012.

Cazcarro, I., Hoekstra, A. Y., and Sánchez Chóliz, J.: The water footprint of tourism in Spain, Tourism Manage., 40, 90-101, 2014.

Chapagain, A. and Hoekstra, A.: Water Footprints of Nations: Volume 1: Main Report, UNESCO-IHE Delft, Delft, 2004.

Chapagain, A. and Hoekstra, A. Y.: The blue, green and grey water footprint of rice from production and consumption perspectives, Ecol. Econ., 70, 749-758, 2011.

Chapagain, A. K. and Hoekstra, A. Y.: Virtual water flows between nations in relation to trade in livestock and livestock products, UNESCO-IHE, Delft, 2003.

Chapagain, A. K. and Orr, S.: An improved water footprint methodology linking global consumption to local water resources: a case of Spanish tomatoes, J. Environ. Manage., 90, 1219-1228, 2009.

Chapagain, A. K. and Tickner, D.: Water footprint: Help or hindrance?, Water Alternatives, 5, 563-581, 2012.

Chapagain, A. K., Hoekstra, A. Y., Savenije, H. H. G., and Gautam, R.: The water footprint of cotton consumption: as assessment of the impact of worldwide consumption of cotton products on the water resources in the cotton producing countries, Ecol. Econ., 60, 186-203, 2006.

Chen, Z. M. and Chen, G. Q.: Virtual water accounting for the globalized world economy: national water footprint and international virtual water trade, Ecol. Indic., 28, 142-149, 2013.

Coca-Cola and Nature Conservancy: Product Water Footprint Assessments: Practical Application in Corporate Water Stewardship, The Coca-Cola Company, Atlanta, 2010.

Cooper, T., Fallender, S., Pafumi, J., Dettling, J., Humbert, S., and Lessard, L.: A semiconductor company's examination of its water footprint approach, in: ISSST 2011: IEEE International Symposium on Sustainable Systems and Technology, Chicago, doi:10.1109/ISSST.2011.5936865, 16-18 May 2011.

Deurer, M., Green, S. R., Clothier, B. E., and Mowatt, A.: Can product water footprints indicate the hydrological impact of primary production? - A case study of New Zealand kiwifruit, J. Hydrol., 408, 246-256, 2011.

Döll, P., Kaspar, F., and Lehner, B.: A global hydrological model for deriving water availability indicators: model tuning and validation, J. Hydrol., 270, 105-134, 2003.

Dumont, A., Salmoral, G., and Llamas, M. R.: The water footprint of a river basin with a special focus on groundwater: the case of Guadalquivir basin (Spain), Water Resources and Industry, 1, 60-76, 2013.

Ercin, A. E., Aldaya, M. M., and Hoekstra, A. Y.: CCorporate Water Footprint Accounting and Impact Assessment: The Case of the Water Footprint of a Sugar-Containing Carbonated Beverage, Water Resour. Manag., 25, 721-741, 2011.

Ercin, A. E. and Hoekstra, A. Y.: Water footprint scenarios for 2050: A global analysis, Environ. Int., 64, 71-82, 2014.

Ercin, A. E., Mekonnen, M. M., and Hoekstra, A. Y.: Sustainability of national consumption from a water resources perspective: the case study for France, Ecol. Econ., 88, 133-147, 2013. 
Fader, M., Gerten, D., Thammer, M., Heinke, J., Lotze-Campen, H., Lucht, W., and Cramer, W.: Internal and external green-blue agricultural water footprints of nations, and related water and land savings through trade, Hydrol. Earth Syst. Sci., 15, 1641-1660, doi:10.5194/hess-15-1641-2011, 2011.

Falkenmark, M.: Fresh water - time for a modified approach, Ambio, 15, 192-200, 1986.

Falkenmark, M., Rockström, J., and Karlberg, L.: Present and future water requirements for feeding humanity, Food Security, 1, 5969, 2009.

Fang, K., Heijungs, R., and de Snoo, G. R.: Theoretical exploration for the combination of the ecological, energy, carbon, and water footprints: Overview of a footprint family, Ecol. Indic., 36, 508518,2014

Food and Agriculture Organization: Aquastat: FAO's Information System on Water and Agriculture, Land and Water Development Division, Food and Agriculture Organization, 2007.

FAO (Food and Agriculture Organization): Statistical Yearbook 2009: available at: http://www.fao.org/ economic/ess/publications-studies/statistical-yearbook/ fao-statistical-yearbook-2009/a-resources/en/, access: 22 September 2010, 2009.

Feng, K., Chapagain, A. K., Suh, S., Pfister, S., and Hubacek, K.: Comparison of bottom-up and top-down approaches to calculating the water footprints of nations, Econ. Systems Res., 23, 371385, 2011.

Feng, K., Siu, Y. L., Guan, D., and Hubacek, K.: Assessing regional virtual water flows and water footprints in the Yellow River Basin, China: a consumption based approach, Appl. Geogr., 32, 691-701, 2012.

Finger, R.: More than the mean - A note on heterogeneity aspects in the assessment of water footprints, Ecol. Indic., 29, 145-147, 2013

Finnveden, G., Hauschild, M. Z., Ekvall, T., Guinée, J., Heijungs, R., Hellweg, S., Köhler, A., Pennington, D., and Sangwon, S.: Recent developments in life cycle assessment, J. Environ. Manage., 91, 1-21, 2009

Flachmann, C., Mayer, H., and Manzel, K.: Water Footprint of Food Products in Germany, Statistisches Bundesamt (Federal Statistical Office of Germany), Wiesbaden, 2012.

Francke, I. C. M. and Castro, J. F. W.: Carbon and water footprint analysis of a soapbar produced in Brazil by Natura Cosmetics, Water Resourc. Ind., 1-2, 37-48, doi:10.1016/j.wri.2013.03.003, 2013

Franke, N. A., Boyacioglu, H., and Hoekstra, A. Y.: Grey water footprint accounting: Tier 1 supporting guidelines, UNESCOIHE Institute for Water Education, Delft, 2013.

Galli, A., Wiedmann, T., Ercin, E., Knoblauch, D., Ewing, B., and Giljum, S.: Integrated ecological, carbon and water footprint into a "footprint family" of indicators: definition and role in tracking human pressure on the planet, Ecol. Indic., 16, 100-112, 2012.

Gawel, E. and Bernsen, K.: Do we really need a water footprint? Global trade, water scarcity and the limite role of virtual water, GAIA, 20, 162-167, 2011a.

Gawel, E. and Bernsen, K.: The colour of water: what does it tell us about scarcity? Reaction to two articles regarding the virtual water concept, GAIA, 20, 224-228, 2011b.
Gawel, E. and Bernsen, K.: What is wrong with virtual water trading? On the limitations of the virtual water concept, Environ Plann. C, 31, 168-181, 2013.

Gerbens-Leenes, P. W., Hoekstra, A. Y., and van der Meer, T.: The water footprint of energy from biomass: a quantitative assessment and consequences of an increasing share of bio-energy in energy supply, Ecol. Econ., 68, 1052-1060, 2009.

Gerbens-Leenes, P. W., Mekonnen, M. M., and Hoekstra, A. Y.: The water footprint of poultry, pork and beef: A comparative study in different countries and production systems, Water Resources and Industry, 1-2, 25-36, doi:10.1016/j.wri.2013.03.001, 2013.

Gleick, P. H.: Water use, Annu. Rev. Env. Resour., 28, 275-314, 2003.

Global Footprint Network: National Ecological Footprint and Biocapacity for 2007: Results from National Footprint Accounts 2010 edition, Global Footprint Network, Oakland, USA, 2010.

Gooch, G. and Stalnacke, P.: Science, Policy and Stakeholders in Water Management: an Integrated Approach to River Basin Management, Earthscan, London, 2010.

Guieysse, B., Bechet, Q., and Stilton, A.: Variability and uncertainty in water demand and water footprint assessments of fresh algae cultivation based on case studies from five climatic regions, Bioresource Technol., 128, 317-323, 2013.

Hadjikakou, M., Chenoweth, J., and Miller, G.: Estimating the direct and indirect water use of tourism in the eastern Mediterranean, J. Environ. Manage., 114, 548-556, 2013.

Hanasaki, N., Kanae, S., Oki, T., Masuda, K., Motoya, K., Shirakawa, N., Shen, Y., and Tanaka, K.: An integrated model for the assessment of global water resources - Part 2: Applications and assessments, Hydrol. Earth Syst. Sci., 12, 1027-1037, doi:10.5194/hess-12-1027-2008, 2008.

Herath, I., Deurer, M., Horne, D., Singh, R., and Clothier, B.: The water footprint of hydroelectricity: a methodological comparison from a case study in New Zealand, J. Clean. Prod., 19, 1582 1589, 2011.

Hoekstra, A. Y.: Human appropriation of natural capital: a comparison of ecological footprint and water footprint analysis, Ecol. Econ., 68, 1963-11974, 2009.

Hoekstra, A. Y.: The Global Dimension of Water Governance: Why the River Basin Approach Is No Longer Sufficient and Why Cooperative Action at Global Level Is Needed, Water, 3, 21-46, 2011.

Hoekstra, A. Y.: Wise freshwater allocation: Water footprint caps by river basin, benchmarks by product and fair water footprint shares by community, UNESCO-IHE, Delft, 2013.

Hoekstra, A. Y. and Chapagain, A. K.: Water footprints of nations: Water use by people as a function of their consumption pattern, Water Resour. Manag., 21, 35-48, 2006.

Hoekstra, A. Y. and Chapagain, A. K.: The water footprints of Morocco and the Netherlands: global water use as a result of domestic consumption of agricultural commodities, Ecol. Econ., 64, 143-151, 2007.

Hoekstra, A. Y. and Chapagain, A. K.: Globalization of Water: Sharing the Planet's Freshwater Resources, Blackwell Publishing, Oxford, 2008.

Hoekstra, A. Y. and Hung, P. Q.: Virtual water trade: a quantification of virtual water flows between nations in relation to international crop trade, IHE Delft, Delft, 2002. 
Hoekstra, A. Y. and Mekonnen, M. M.: Reply to Ridoutt and Huang: From water footprint assessment to policy, P. Natl. Acad. Sci. USA, 109, E1425, doi:10.1073/pnas.1205186109, 2012a.

Hoekstra, A. Y. and Mekonnen, M. M.: The water footprint of humanity, P. Natl. Acad. Sci. USA, 109, 3232-3237, 2012 b.

Hoekstra, A. Y., Chapagain, A. K., Aldaya, M. M., and Mekonnen, M. M.: Water Footprint Manual: State of the Art 2009, Water Footprint Network, Enschede, 2009a.

Hoekstra, A. Y., Chapagain, A. K., Aldaya, M. M., and Mekonnen, M. M.: Water Footprint Manual: State of the Art 2009, Water Footprint Network, Enschede, 2009b.

Hoekstra, A. Y., Gerbens-Leenes, W., and van der Meer, T. H.: Reply to Pfister and Hellweg: Water footprint accounting, impact assessment, and life-cycle assessment, P. Natl. Acad. Sci. USA, 106, E114, doi:10.1073/pnas.0909948106, 2009c.

Hoekstra, A. Y., Chapagain, A. K., Aldaya, M. M., and Mekonnen, M. M.: The Water Footprint Assessment Manual: Setting the Global Standard, Earthscan, London, 224 pp., 2011.

Hoekstra, A. Y., Mekonnen, M. M., Chapagain, A. K., Mathews, R. E., and Richter, B. D.: Global monthly water scarcity: blue water footprints versus blue water availability, PLoS ONE, 7, e32688, doi:10.1371/journal.pone.0032688, 2012.

ISO (International Organization for Standardization): ISO Briefing Note: Measuring the impact of water use and promoting efficiency in water management, available at: http://www.iso. org/iso/iso14046_briefing_note.pdf (last access: 16 June 2014), 2014.

Jefferies, D., Muñoz, I., Hodges, J., King, V. J., Aldaya, M., Ercin, A. E., Milà i Canals, L., and Hoekstra, A. Y.: Water footprint and life cycle assessment as approaches to assess potential impacts of products on water consumption. Key learning points from pilot studies on tea and margarine, J. Clean. Prod., 33, 155-166, 2012.

Johnston, A. E. and Dawson, C. J.: Phospherus in Agriculture and in Relation to Water Quality, Agricultural Industries Confederation, Peterborough, 2005.

Juntunen, M. L., Hammar, T., and Rikala, R.: Leaching of nitrogen and phosphorus during production of forest seedlings in containers, J. Environ. Qual., 31, 1868-1874, 2002.

Kounina, A., Margni, M., Bayart, J.-B., Boulay, A.-M., Berger, M., Bulle, C., Frischknecht, R., Koehler, A., i Canals, L. M., and Motoshita, M.: Review of methods addressing freshwater use in life cycle inventory and impact assessment, Int. J. Life Cycle Ass., 18, 707-721, 2013.

Launiainen, S., Futter, M. N., Ellison, D., Clarke, N., Finér, L., Högbom, L., Laurén, A., and Ring, E.: Is the Water Footprint an Appropriate Tool for Forestry and Forest Products: The Fennoscandian Case, AMBIO, 43, 244-256, doi:10.1007/s13280-0130380-z, 2014.

Lenzen, M. and Foran, B.: An input-output analysis of Australian water usage, Water Policy, 3, 321-340, 2001.

Leontief, W.: Environmental repercussions and the economic structure: an input-output approach, Rev. Econ. Statistics, 52, 262$271,1970$.

Mason, N.: Uncertain Frontiers: Mapping New Corporate Engagement in Water Security, Overseas Development Institute, London, 2013.

Mekonnen, M. M. and Hoekstra, A. Y.: The green, blue and grey water footprint of crops and derived crop products, UNESCOIHE Institute for Water Education, Delft, the Netherlands, 2010a.
Mekonnen, M. M. and Hoekstra, A. Y.: A global and high-resolution assessment of the green, blue and grey water footprint of wheat, Hydrol. Earth Syst. Sci., 14, 1259-1276, doi:10.5194/hess-141259-2010, 2010b.

Mekonnen, M. M. and Hoekstra, A. Y.: National water footprint accounts: the green, blue and grey water footprint of production and consumption, UNESCO-IHE, Delft, 2011a.

Mekonnen, M. M. and Hoekstra, A. Y.: The green, blue and grey water footprint of crops and derived crop products, Hydrol. Earth Syst. Sci., 15, 1577-1600, doi:10.5194/hess-15-15772011, 2011 b.

Mekonnen, M. M. and Hoekstra, A. Y.: A global assessment of the water footprint of farm animal products, Ecosystems, 15, 401415, 2012a.

Mekonnen, M. M. and Hoekstra, A. Y.: The blue water footprint of electricity from hydropower, Hydrol. Earth Syst. Sci., 16, 179187, doi:10.5194/hess-16-179-2012, 2012b.

Mekonnen, M. M. and Hoekstra, A. Y.: Water footprint benchmarks for crop production, UNESCO-IHE, Delft, 2013.

Mekonnen, M. M., Hoekstra, A. Y., and Becht, R.: Mitigating the water footprint of export cut flowers from the Lake Naivasha Basin, Kenya, Water Resour. Manag., 26, 3725-3742, 2012.

Milà i Canals, L., Chenoweth, J., Chapagain, A., Orr, S., Antón, A., and Clift, R.: Assessing freshwater use impacts in LCA: Part I - Inventory modelling and characterisation factors for the main impact pathways, Int. J. Life Cycle Ass., 14, 28-42, 2009.

Mitchell, B.: Integrated water management, in: Integrated Water Management: International Experiences and Perspectives, edited by: Mitchell, B., Belhaven Press, London, 1-21, 1990.

Morrison, J., Schulte, P., and Schenck, R.: Corporate Water Accounting: an Analysis of Methods and Tools for Measuring Water Use and Its Impact, UNEP/Pacific Institute, Oakland, 2010.

Mostert, E. and Raadgever, G. T.: Seven rules for researchers to increase their impact on the policy process, Hydrol. Earth Syst. Sci., 12, 1087-1096, doi:10.5194/hess-12-1087-2008, 2008.

Motoshita, M., Itsubo, N., and Inaba, A.: Development of impact factors on damage to health by infectious diseases caused by domestic water scarcity, Int. J. Life Cycle Ass., 16, 65-73, 2011.

Munksgaard, J., Wier, M., Lenzen, M., and Dey, C.: Using inputoutput analysis to measure the environmental pressure of consumption at different spatial levels, J. Ind. Ecol., 9, 169-185, 2005.

Nazer, D. W., Siebel, M. A., van der Zaag, P., Mimi, Z., and Gijzen, H. J.: Water footprint of the Palestinians in the West Bank, J. Am. Water Resour. As., 44, 449-458, 2008.

Nestlé: Meeting the Global Water Challenge: Creating Shared Value Summary Report 2011, Nestlé, Vevey, 2011.

Núñez, M., Pfister, S., Antón, A., Muñoz, P., Hellweg, S., Koehler, A., and Rieradevall, J.: Assessing the Environmental Impact of Water Consumption by Energy Crops Grown in Spain, J. Ind. Ecol., 17, 90-102, 2012.

Oki, T. and Kanae, S.: Global hydrological cycles and world water resources, Science, 313, 1068-1072, 2006.

Pepsi Co: Environmental Sustainability Report 2009/10: Path to Zero, Pepsi Co UK \& Ireland, London, 2011.

Perry, C.: Water footprints: Path to enlightenment, or false trail?, Agr. Water Manage., 134, 119-125, 2014.

Pfister, S. and Hellweg, S.: The water "shoesize" vs. footprint of bioenergy, P. Natl. Acad. Sci. USA, 106, E93-94, 2009. 
Pfister, S., Koehler, A., and Hellweg, S.: Assessing the environmental impacts of freshwater consumption in LCA, Environ. Sci. Techol., 43, 4098-4104, 2009.

Raimbault, M. and Humbert, S.: ISO considers potential standard on water footprint, available at: http://www.iso.org/iso/ isofocusplus_bonus_water-footprint, last access: 21 June 2012, 2011.

Raisio's $\mathrm{H}_{2} \mathrm{O}$ Label: available at: http://www.raisio.com/www/ page/4397 (last access: 21 February 2010), 2010.

Rees, W. E.: Ecological footprints and appropriated carrying capacity: what urban economics leaves out, Environ. Urban., 4, 121130, 1992.

Rep, J.: From Forest to Paper, the Story of Our Water Footprint, UPM-Kymmene, Helsinki, 2011.

Ridoutt, B. G. and Huang, J.: Environmental relevance - the key to understanding water footprints, P. Natl. Acad. Sci. USA, 109, E1424, doi:10.1073/pnas.1203809109, 2012.

Ridoutt, B. G. and Pfister, S.: A revised approach to water footprinting to make transparent the impacts of consumption and production on global freshwater scarcity, Global Environ. Chang., 20, 113-120, 2010a.

Ridoutt, B. G. and Pfister, S.: Reducing humanity's water footprint, Environ. Sci. Techol., 44, 6019-6021, doi:10.1021/es101907z, 2010b.

Ridoutt, B. G. and Pfister, S.: A new water footprint calculation method integrating consumptive and degradative water use into a single stand-alone weighted indicator, Int. J. Life Cycle Ass., 18, 204-207, 2013.

Ridoutt, B. G., Sanguansri, P., Freer, M., and Harper, G. S.: Water footprint of livestock: comparison of six geographically defined beef production systems, Int. J. Life Cycle Ass., 17, 165-175, 2012a.

Ridoutt, B. G., Sanguansri, P., Nolan, M., and Marks, N.: Meat consumption and water scarcity: beware of generalizations, J. Clean. Prod., 28, 127-133, 2012b.

Ruini, L., Marino, M., Pignatelli, S., Laio, F., and Ridolfi, L.: Water footprint of a large-sized food company: the case of Barilla pasta production, Water Resources and Industry, 1-2, 7-24, doi:10.1016/j.wri.2013.04.002, 2013.

Ruprecht, J. K. and Schofield, N. J.: Analysis of streamflow generation following deforestation in southwest Western Australia, J. Hydrol., 105, 1-17, 1989.

SABMiller and WWF-UK: Water Footprinting: Identifying \& Addressing Water Risks in the Value Chain, SABMiller and WWF, Woking, 2009.

SABMiller, WWF-UK, and GIZ: Water Futures: Addressing Shared Water Challenges Through Collective Action, SAB Miller, Woking, Surrey, 2011.

Sausse, C.: On the water footpring of energy from biomass: A comment, Ecol. Econ., 71, 1-3, 2011.

Seckler, D., Amarasighe, U., Molden, D., de Silva, R., and Barker, R.: World Water Demand and Supply, 1990 to 2025: Scenarios and Issues, Research Report 19, International Water Management Institute, Colombo, 1998.

Siebert, S. and Döll, P.: Quantifying blue and green virtual water contents in global crop production as well as potential production losses without irrigation, J. Hydrol., 384, 198-217, 2010.

Tamea, S., Allamano, P., Carr, J. A., Claps, P., Laio, F., and Ridolfi, L.: Local and global perspectives on the virtual water trade, Hy- drol. Earth Syst. Sci., 17, 1205-1215, doi:10.5194/hess-17-12052013, 2013.

Thomann, R. V. and Mueller, J. A.: Principles of Surface Water Quality Modeling and Control, Harper \& Row Publishers, 1987.

Unilever: Our water footprint, available at: http://www.unilever. com/sustainable-living/water/footprint/ (last access: 21 June 2012), 2012.

Vanham, D. and Bidoglio, G.: A review on the indicator water footprint for the EU 28, Ecol. Indic., 26, 61-75, 2013.

Van Oel, P. R. and Hoekstra, A. Y.: Towards Quantification of the Water Footprint of Paper: A First Estimate of its Consumptive Component, Water Resour. Manag., 26, 733-749, 2012.

van Oel, P. R., Mekonnen, M. M., and Hoekstra, A. Y.: The external water footprint of the Netherlands: geographcially-explicit quantification and impact assessment, Ecol. Econ., 69, 82-92, 2009.

Velázquez, E.: An input-output model of water consumption: Analysing intersectoral water relationships in Andalusia, Ecol. Econ., 56, 226- 240, 2006.

Velázquez,, E., Madrid, C., and Beltran, M. J.: Rethinking the Concepts of Virtual Water and Water footprint in Relation to the Production-Consumption Binomial and the Water-Energy Nexus, Water Resour. Manag., 25, 743-761, 2011.

Verma, S., Kampman, D. A., van der Zaag, P., and Hoekstra, A. Y.: Going against the flow: A critical analysis of inter-state virtual water trade in the context of India's National River Linking Program, Phys. Chem. Earth, 34, 261-269, 2009.

Vörösmarty, C., Green, P., Salisbury, J., and Lammers, R.: Global Water Resources: Vulnerability from Climate Change and Population Growth, Science, 289, 284-288, 2000.

Vörösmarty, C. J., McIntyre, P. B., Gessner, M. O., Dudgeon, D., Prusevich, A., Green, P., Glidden, S., Bunn, S. E., Sullivan, C. A., Reidy Liermann, C., and Davies, P. M.: Global threats to human water security and river biodiversity, Nature, 467, 555-561, 2010.

Wang, Z., Huang, K., Yang, S., and Yu, Y.: An Input-output Approach to Evaluate the Water Footprint and Virtual Water Trade of Beijing, China, J. Clean. Prod., 42, 172-179, 2013.

Ward, F. A. and Pulido-Velazquez, M.: Water conservation in irrigation can increase water use, P. Natl. Acad. Sci. USA, 105 , 18215-18220, 2008.

Water Footprint Network, available at: http://www.waterfootprint. org (last access: 21 June 2012), 2012.

Wichelns, D.: Virtual Water: A Helpful Perspective, but not a Sufficient Policy Criterion, Water Resour. Manag., 24, 2203-2219, 2010a.

Wichelns, D.: Virtual water and water footprints offer limited insight regarding important policy questions, Int. J. Water Resourc. D., 26, 639-651, 2010b.

Wichelns, D.: Virtual water and water footprints: compelling notions, but notably flawed: reaction to two articles regard the virtual water concept, GAIA, 20, 171-175, 2011a.

Wichelns, D.: Do the virtual water and water footprint perspectives enhance policy discussions?, Int. J. Water Resour. D., 27, 633645, 2011b.

Witmer, M. C. H. and Cleij, P.: Water Footprint: Useful for Sustainability Policies?, PBL Netherlands Environmental Assessment Agency, The Hague, 2012.

WWF: Living Planet Report 2012, WWF International, Gland, Switzerland, 2012. 
Yu, Y., Hubacek, K., Feng, K., and Guan, D.: Assessing the regional and global water footprints for the UK, Ecol. Econ., 69, 11401147, 2010.

Zhang, C. and Anadon, L. D.: A multi-regional input-output analysis of domestic virtual water trade and provincial water footprint in China, Ecol. Econ., 100, 159-172, 2014.

Zhang, Z., Yang, H., and Shi, M.: Analyses of water footprint of Beijing in an interregional input-output framework, Ecol. Econ., 70, 2494-2502, 2011.

Zhang, Z., Shi, M., and Yang, H.: Understanding Beijing's Water Challenge: A Decomposition Analysis of Changes in Beijing's Water Footprint between 1997 and 2007, Environ. Sci. Technol., 46, 1273-12380, 2012.

Zhuo, L., Mekonnen, M. M., and Hoekstra, A. Y.: Sensitivity and uncertainty in crop water footprint accounting: a case study for the Yellow River Basin, Hydrol. Earth Syst. Sci. Discuss., 11, 135-167, doi:10.5194/hessd-11-135-2014, 2014.
Zoumides, C., Bruggeman, A., and Zachariadis, T.: Global versus local crop water footprints: the case of Cyprus, in: Proceedings of the Session "Solving the Water Crisis: Common Action Toward a Sustainable Water Footprint", Planet under Pressure Conference, London, 26 March 2012, 7-27, 2012.

Zoumides, C., Bruggeman, A., Zachariadis, T., and Pashiardis, S.: Quantifying the Poorly Known Role of Groundwater in Agriculture: the Case of Cyprus, Water Resour. Manag., 27, 2501-2514, 2013.

Zoumides, C., Bruggeman, A., Hadjikakou, M., and Zachariadis, T.: Policy-relevant indicators for semi-arid nations: The water footprint of crop production and supply utilization of Cyprus, Ecol. Indic., 43, 205-214, 2014. 